\title{
Distribution of $N$-acetyltransferase Type 1 (NAT1) genotypes and alleles in a Turkish Population
}

\author{
Serdal Arslan, Naci Degerli and Fevzi Bardakci \\ Molecular Biology Research Group, Department of Biology, Faculty of Science and Literature, \\ Cumhuriyet University, Turkey.
}

\begin{abstract}
NAT1 is an intronless gene on chromosome 8p21.3 encoding a 290-amino-acid-long protein showing acetyltransferase activity. Some 26 alleles of NAT1 gene have been identified in human populations. In the present study we determined the distributions of NAT1 genotypes and alleles in a sample of 201 individuals from the Turkish population in Central Anatolia. The most frequent genotypes were NAT1*4/NAT1*4 (51.74\%), NAT1*10/NAT1*4 (22.39\%), NAT1*11/NAT1*4 (7.46), NAT1*10/NAT1*10 (3.98\%). Frequencies of NAT1*3, *4 (wild-type), *10 and *11 alleles were $3.73 \%, 69.6 \%, 17.66 \%$ and $7.2 \%$, respectively. The frequency of $N A T 1^{*} 11$ was the highest amongst the populations studied so far, the other allele frequencies being close to those described in Caucasian populations.
\end{abstract}

Key words: NAT1 gene, genetic polymorphism, molecular epidemiology, Turkish population.

Received: July 4, 2003; Accepted: December 16, 2003.

NAT1 and NAT2 are isoenzymes that catalyze the $N$-acetylation of aromatic amine and hydrazine drugs. While substrates of NAT2 enzyme are isoniazid, sulfamethazine, 2-aminofluorene and 4-aminobiphenyl, NAT1 enzyme has para-aminosalicylic acid (PAS), para-aminobenzoic acid (PABA) and sulfanilamide as substrates (Deguchi et al., 1990; Grant et al., 1992).

The polymorphism of NAT1 gene was first described about a decade ago (Vatsis and Weber, 1993), and 26 alleles have been identified in human populations (Hein et al., 2000), NAT1*3, NAT1*4, NAT1*5,NAT1*10 and $N A T 1 * 11$ being the most common alleles reported. A single mutation or a combination of multiple nucleotide substitutions and insertions/deletions are responsible for the allelic variants of $N A T 1$. While some variants $(N A T 1 * 11, * 20$ and *23) do not lead to differences in activity (Hughes et al., 1998; Lin et al., 1998), others result in increase (e.g. $N A T 1 * 21, N A T 1 * 24$ and $N A T 1 * 25$ ) (Lin et al., 1998), decrease or absence of activity $(N A T 1 * 14, * 15, * 17, * 19$ and *22) (Hughes et al., 1998; Lin et al., 1998; Butcher et al., 1998) with respect to the enzyme encoded by the wild-type allele $\left(N A T 1^{* 4}\right)$. In a German population, Bruhn et al. (1999) found that enzyme activity in carriers of $N A T 1 * 3$, *4 and $* 10$ did not differ. On the other hand, $N A T 1 * 11$ and $* 14$ appeared to be low-activity alleles while $N A T 1 * 15$ was a null allele. In contrast, recent data suggest that the enzyme encoded by $N A T 1^{*} 11$ allele exhibits higher NAT1 activity

Send correspondence to Assoc. Prof. Dr. Fevzi Bardakci. Cumhuriyet University, Faculty of Science and Literature, Department of Biology, 58140 Sivas, Turkey. E-mail: bardakci@ cumhuriyet.edu.tr. relative to the product of the wild-type $N A T 1 * 4$ allele (reviewed in Zheng et al. 1999; de Leon et al. 2000; Loktionov et al. 2002).

Much emphasis has been given to $N A T 1 * 10$ allele, because a change in the consensus polyadenilation signal was suggested to be correlated with higher enzyme activity in colon, bladder and liver tissues (Bell, et al., 1995a; Zenser et al., 1996). Several studies have also demonstrated an association between $N A T 1 * 10$ allele and colon, gastric, urinary bladder, laryngeal and head tumors as well as the development of environmental borne diseases (Bell et al., 1995a,b; Taylor et al., 1995; Katoh et al., 2000).

In this study we determined the distribution of NAT1 genotypes and alleles in a Turkish population sample using restriction fragment length polymorphism (RFLP) and single-strand conformation polymorphism (SSCP) assays.

Subjects: Venous blood was taken from 201 randomly selected non-cancer volunteers (116 females and 85 males) attending the Cumhuriyet University Hospital, Sivas (Central Anatolia, Turkey) as outpatients, between January and February 2002. The mean ages of male and female individuals were $44.22 \pm 14.80$ (16-76) and $42.03 \pm 13.96$ (17-86) years, respectively. The study was carried out after approval of the hospital ethical committee.

PCR-SSCP analysis of the NAT1 gene: A $1216 \mathrm{bp}$ long fragment of the NAT1 gene, consisting of the $870 \mathrm{bp}$ intronless coding region, the $278 \mathrm{bp}$ 3'UTR and the $68 \mathrm{bp}$ 5'UTR, was amplified by PCR of genomic DNA obtained from peripheral blood leukocytes. PCR was accomplished in a total of $25 \mu \mathrm{L}$ volume containing $0.2 \mathrm{mM}$ each primer 
(sense 5'TAAAAGTAAAATGATTTTGCTTTCG3' and anti-sense 5'GCTTTCTAGCATAAATCACCAA3'), $75 \mathrm{mM}$ Tris-HCI (pH 8.8 at $\left.25^{\circ} \mathrm{C}\right), 20 \mathrm{mM}\left(\mathrm{NH}_{4}\right)_{2} \mathrm{SO}_{4}$, $0.01 \%$ Tween 20 and $1.5 \mathrm{mM} \mathrm{MgCl}_{2}, 0.2 \mathrm{mM}$ each dNTP (MBI Fermentas), 0.6 units Taq DNA polymerase (MBI Fermentas) and $250 \mathrm{ng}$ genomic DNA. The mixture was subjected to $2 \mathrm{~min}$ initial denaturation at $94^{\circ} \mathrm{C}$ followed by 32 cycles of $1 \mathrm{~min}$ at $94{ }^{\circ} \mathrm{C}, 1 \mathrm{~min}$ at $61^{\circ} \mathrm{C}$ and $1.5 \mathrm{~min}$ at $72{ }^{\circ} \mathrm{C}$ with a 5 min-extension step at $72{ }^{\circ} \mathrm{C}$, in a thermal cycler (Techne, UK). The SSCP protocol described by Lo-Guidice et al. (2000) was followed, with some modifications. PCR products were digested by TfiI (New England Biolabs, Beverly, MA, USA). Electrophoresis was performed on an $8 \%$ non-denaturing polyacrylamide gel, and the patterns analyzed after silver staining.

PCR-RFLP Analysis of the NAT1 gene: A RFLPassay was used to confirm the presence of $N A T 1 * 11$ alleles, allowing to distinguish a $\mathrm{T}\left(N A T 1^{*} 4\right)$ from a $\mathrm{G}\left(N A T 1^{*} 11\right)$ at the nucleotide 640, as described by Lo-Guidice et al. (2000). The PCR products were digested with AlwNI (Fermentas). This enzyme cleaves $N A T 1^{*} 11$ into three fragments $(241,451$ and $496 \mathrm{bp})$, but other alleles into two fragments (451 and $746 \mathrm{bp}$ ). Therefore, restriction digestion produces three fragments $(241,451$ and $496 \mathrm{bp})$ for $N A T 1^{*} 11 / N A T 1 * 11$ genotype, and four fragments (241, 451, $496 \mathrm{bp}$ and $746 \mathrm{bp)}$ ) for $N A T 1 * 11 /$ any other allele genotypes.

The NAT1 genotype distribution of the 201 individuals from the Turkish population is shown in Table 1. The ten most frequent described genotypes, as well as eight rare genotypes involving alleles not identifiable by SSCP analysis $(N A T 1 * 4 /$ others $)$ were found. NAT1*4/NAT1*4 $(53.89 \%), \quad N A T 1 * 4 / N A T 1 * 10(22.39 \%)$ and $N A T 1 * 41$ $N A T 1 * 11(7.46 \%)$ were the most common ones. The frequencies of the different alleles are shown in Table 2. The wild-type allele $N A T{ }^{*} 4$ had a frequency of $69.65 \%$. The frequencies of $N A T 1 * 10, * 11, * 3$ and of the non-identifiable alleles were $17.41 \%, 7.21 \%, 3.73 \%$ and $2 \%$, respectively.

The frequencies of $N A T 1 * 3, N A T 1 * 4$ and $N A T 1 * 10$ alleles observed were close to those found in German (Henning et al., 1999), Canadian (Hughes et al., 1998), and French (Lo-Guidice et al., 2000) populations. A striking difference in the Turkish population was the highest $N A T 1^{*} 11$ frequency $(7.2 \%)$. Although this allele was not found in the French population (Lo-Guidice et al., 2000), it has been reported with a lower frequency in German $(2.7 \%$ by Henning et al., 1999 and 3.34\% by Bruhn et al. 1999) and in Canadian (2.1\% by Hughes et al., 1998) populations. These populations differ from the Japanese who present the $N A T{ }^{*} 10$ allele as the most frequent, and among whom $N A T 1 * 3$ and $* 11$ alleles were never found (Yang et al., 2000). In Indian, Malay and Chinese populations, Zhao et al. (1998) reported a much higher $N A T 1^{*} 10$ and $N A T 1 * 3$ allele frequencies than those found in Caucasians.
Table 1 - Distribution of observed and expected numbers of NATI genotypes in a sample from the Turkish population.

\begin{tabular}{lcc}
\hline \multirow{2}{*}{ Genotypes } & \multicolumn{2}{c}{ Number of individuals } \\
\cline { 2 - 3 } & Observed & Expected \\
\hline$N A T 1 * 3 / N A T 1 * 3$ & 2 & 0.262 \\
$N A T 1 * 3 / N A T 1 * 4$ & 4 & 10.474 \\
$N A T 1 * 4 / N A T 1 * 4$ & 104 & 97.407 \\
$N A T 1 * 10 / N A T 1 * 3$ & 5 & 2.619 \\
$N A T 1 * 10 / N A T 1 * 4$ & 45 & 48.878 \\
$N A T 1 * 10 / N A T 1 * 10$ & 8 & 6.022 \\
$N A T 1 * 11 / N A T 1 * 3$ & 2 & 1.085 \\
$N A T 1 * 11 / N A T 1 * 4$ & 15 & 20.250 \\
$N A T 1 * 11 / N A T 1 * 10$ & 4 & 5.062 \\
$N A T 1 * 11 / N A T 1 * 11$ & 4 & 1.013 \\
$N A T 1 * 4 /$ other & 8 & 5.586 \\
$N A T 1 * 3 /$ other & 0 & 0.299 \\
NATI*10/other & 0 & 1.397 \\
NAT1*11/other & 0 & 0.579 \\
\hline
\end{tabular}

A small departure (significant at the 5\% level) from Hardy-Weinberg genotype proportions was observed (chi-squared $=12.31$; d.f. $=4 ; \mathrm{p}=0.015$ ). Only the deficiency of $N A T 1 * 3 / N A T 1 * 4$ heterozygotes seems to contribute significantly to the obtained chi-squared figure. Both the sample size and its heterogeneous ethnic composition are the best explanation for this finding.

Yang et al. (2000) reported a higher activity of the enzyme encoded by $N A T 1 * 10$ allele in a Japanese population, with $N A T 1 * 4 / N A T 1 * 10$ female heterozygotes having higher enzyme activity than $N A T 1 * 4 / N A T 1 * 4$ females. Wikman et al., (2001) considered individuals with $N A T 1 * 10$ allele as rapid acetylators unless when combined with a slow allele. In contrast, Bruhn et al. (1999) did not detect increased enzyme activities in association with $N A T 1 * 4 / * 4, N A T 1 * 4 / * 10$ and $N A T 1 * 10 / * 10$ genotypes in a German population. Jourenkova-Mironova et al. (1999) have also found low frequencies of NAT1 homozygous rapid acetylator genotypes $(N A T 1 * 10 / * 11$ and $N A T 1 * 10 /$ *10). Associations between the $N A T 1 * 10$ allele and a high enzyme activity with oral (Katoh et al., 1998), colon (Bell et al., 1995b), urinary bladder (Taylor et al., 1995), head and neck (Olshan et al., 2000) and gastric (Katoh et al.,

Table 2 - Frequencies of $N A T 1$ alleles in a sample from the Turkish population.

\begin{tabular}{llc}
\hline Alleles & Mutations & N. of alleles (\%) \\
\hline$N A T 1 * 3$ & $1095 \mathrm{C}>\mathrm{A}$ & $15(3.73)$ \\
$N A T 1 * 4$ & Wild-type & $279(69.65)$ \\
$N A T 1 * 10$ & $1088 \mathrm{~T}>\mathrm{A}, 1095 \mathrm{C}>\mathrm{A}$ & $71(17.41)$ \\
$N A T 1 * 11$ & $-344 \mathrm{C}>\mathrm{T},-40 \mathrm{~A}>\mathrm{T}, 445 \mathrm{G}>\mathrm{A}$, & $29(7.21)$ \\
& $459 \mathrm{G}>\mathrm{A}, 640 \mathrm{~T}>\mathrm{G}, 1095 \mathrm{C}>\mathrm{A}$, & \\
& $1065-1090 \mathrm{del}$ & $8(1.99)$ \\
\hline
\end{tabular}


2000) cancers have been described. In addition, linkage disequilibrium between $N A T 1^{*} 10$ and $N A T 2$ alleles has been reported in a German population, with half of the $N A T 1 * 10$ alleles being linked to mutant NAT2 alleles (Henning et al., 1999). NAT1*11 allele, with the highest frequency reported thus far in the Turkish population, has been considered as a putative rapid allele in Caucasians and Black South Africans (Zheng et al. 1999; Loktionov et al. 2002). A possibility deserving investigation is of an association between $N A T 1 * 11$ allele and certain cancers as shown for $N A T 1 * 10$, another rapid acetylator.

\section{Acknowledgments}

This work was supported by grants from the Scientific Research Fund of Cumhuriyet University, Sivas to Fevzi Bardakci (Grant n. F-122).

\section{References}

Bell DA, Badawi AF, Lang NP, Ilett KF, Kadlubar FF and Hirvonen A (1995a) Polymorphism in the $N$-acetyltransferase $1(N A T 1)$ polyadenilation signal: association of $N A T 1 * 10$ allele with higher $N$-acetylation activity in bladder and colon tissue. Cancer Res 55:5226-5229.

Bell DA, Stephens EA, Castranio T, Umbach DM, Watson M, Deakin M, Elder J, Hendrickse C, Duncan H and Strange RC (1995b) Polyadenylation polymorphism in the acetyltransferase 1 gene $(N A T 1)$ increases risk for colorectal cancer. Cancer Res 55:3537-3542.

Bruhn C, Brockmöller J, Cascorbi I, Roots I and Borchert HH (1999) Correlation between genotype and phenotype of the human arylamine $N$-Acetyltransferase Type 1 (NAT1). Biochem Pharmacol 58:1759-1764.

Butcher NJ, Ilett KF and Minchin RF (1998) Functional polymorphism of the human arylamine $N$-acetyltransferase type 1 gene caused by C190T and G560A mutations. Pharmacogenetics 8:67-72.

Deguchi T, Mashimo M and Suzuki T (1990) Correlation between acetylator phenotypes and genotypes of polymorphic arylamine $\mathrm{N}$-acetyltransferase in human liver. J Biol Chem 265:12757-12760.

de Leon JH, Vatsis KP and Weber WW (2000) Characterization of naturally occurring and recombinant human $N$-acetyltransferase- 1 gene variants encoded by $N A T 1^{*}$. Mol Pharmacol 58:288-299.

Grant DM, Vohra P, Avis Y and Ima A (1992) Detection of a new polymorphism of human arylamine $N$-acetyltransferase NAT1 using p-aminosalicylic acid as an in vivo probe. $\mathrm{J} \mathrm{Ba}-$ sic Clin Physiol Pharmacol 3(suppl.):244.

Hein DW, Grant DM and Sim E (2000) Update on consensus arylamine $N$-acetyltransferase gene nomenclature. Pharmacogenetics 10:291-292.

Henning S, Cascorbi I, Münchow B, Jahnke V and Roots I (1999) Association of arylamine $N$-acetyltransferases NAT1 and NAT2 genotypes to laryngeal cancer risk. Pharmacogenetics 9:103-111.

Hughes NC, Janezic SA, MacQuen KL, Jewett MAS, Castranio T, Bell DA and Grand DM (1998) Identification and characterization of variant alleles of human $N$-acetyltransferase $N A T 1$ with defective function using p-aminosalicylate as in-vivo and in-vitro probe. Pharmacogenetics 8:55-66.
Jourenkova-Mironova N, Wikman H, Bouchardy C, Mitrunen K, Dayer P, Benhamous S and Hyrvonen A (1999) Role of arylamine $N$-acetyltransferase 1 and 2 (NAT1 and NAT2) genotypes in susceptibility to oral/pharyngeal and laryngeal cancers. Pharmacogenetics 9:533-537.

Katoh T, Boissy R, Nagata N, Kitagawa K, Kuroda Y, Itoh H, Kawamoto T and Bell DA (2000) Inherited polymorphism in the $N$-actyltransferase 1 (NAT1) and 2 (NAT2) genes and susceptibility to gastric and colorectal adenocarcinoma. Int J Cancer 85:46-49.

Katoh T, Kaneko S, Boissy R, Watson M, Ikemura K and Bell DA (1998) A pilot study testing the association between $N$ acetyltransferases 1 and 2 and risk of oral squamous cell carcinoma in Japanese people. Carcinogenesis 19:1803-1807.

Lin HJ, Probst-Hensch NM, Hughes NC, Sakamato GT, Louie AD, Kau IH, Lin BK, Lee DB, Lin J, Frankl HD, Lee ER, Hardy S, Grant DM and Haile RW (1998) Variants of $N$-acetyltransferase NAT1 and a case-control study of colerectal adenomas. Pharmacogenetics 8:269-281.

Lo-Guidice J-M, Allorge D, Chevalier D, Herve D, Fazio F, Lafitte JJ and Broly F (2000) Molecular analysis of the $N$-acetyltransferase 1 (NAT1) using polymerase chain reaction-restriction-fragment single strand conformation polymorphism assay. Pharmacogenetics 10:293-300.

Loktionov A, Moore W, Spencer SP, Vorster H, Nell T, O’Neill IK, Bringham SA and Cummings JH (2002) Differences in $\mathrm{N}$-acetylation genotypes between Caucasians and Black South Africans: implications for cancer prevention. Cancer Detect Prev 26:15-22.

Olshan AF, Wiessler M, Watson MA and Bell DA (2000) GSTM1, GSTT1, GSTP1, CYP1A1, and NAT1 polymorphism tabacco use, and the risk of head neck cancer. Cancer Epidemiol Biomarkers Prev 9:185-191.

Taylor JA, Umbach D, Stephan E, Paulson D, Robertson C, Mohler JL and Bell DA (1995) Role of the $N$-acetylation polymorphism at NAT1 and NAT2 in smoking-associated bladder cancer. Proc Am Assoc Cancer Res 36:282.

Vatsis KP and Weber WW (1993) Structural heterogeneity of Caucasian $N$-acetyltransferase at the NAT1 gene locus. Arch Biochem Biophys 301:71-76.

Wikman H, Thiel S, Jäger B, Schmezer P, Spiegelhalder B, Edler L, Dienemann H, Kayser K, Schulz V, Drings P, Bartsch H and Risch A (2001) Relevance of $N$-acetyltransferase 1 and 2 (NAT1, NAT2) genetic polymorphisms in non small cell lung cancer susceptibility. Pharmacogenetics 11:157-168.

Yang M, Katoh T, Delongchamp R, Ozowa S, Kohshi K and Kawamoto T (2000) Relationship between NAT1 genotype and phenotype in a Japanese population. Pharmacogenetics 10:225-232.

Zenser TV, Lakshmi VM, Rustan TD, Doll MA, Deitz AC, Davis BB and Hein DW (1996) Human $N$-acetylation of benzidine: role of NAT1 and NAT2. Cancer Res 56: 3941-3947.

Zhao B, Lee EJ, Yeoh PN and Gong NH (1998) Detection of mutations and polymorphism of $N$-acetyltransferase 1 gene in Indian, Malay and Chinese populations. Pharmacogenetics 8:299-304.

Zheng W, Dietz A, Chambell D, Wen W-Q, Cerhan J, Sellers T, Folsom A and Hein DW (1999) $N$-Acetyltransferase 1 genetic polymorphism, cigarette smoking, well-done meat intake, and breast cancer risk. Cancer Epidemiol Biomarkers Prev 8:233-239.

Editor Associado: Francisco Mauro Salzano 